\title{
Dispersions of carbon nanotubes in cholesteric liquid crystals with photoactive components
}

\author{
A.N.Samoilov, S.S.Minenko, L.N.Lisetski, N.I.Lebovka*, \\ M.S.Soskin ${ }^{* *}$, S.I.Torgova
}

Institute for Scintillation Materials, STC "Institute for Single Crystals", National Academy of Sciences of Ukraine, 60 Lenin Ave., 61001 Kharkiv, Ukraine

"F.Ovcharenko Institute of Biocolloidal Chemistry, National Academy of

Sciences of Ukraine, 42 Vernadsky Ave., 03142 Kyiv, Ukraine

* Institute of Physics, National Academy of Sciences of Ukraine, 46 Nauky Ave., 03028 Kyiv, Ukraine

***: Pebedev Physical Institute, Russian Academy of Sciences, 53 Leninskii Ave., 119991 Moscow, Russia

\section{Received July, 2014}

Optical transmission and selective reflection data are reported for dispersions of singlewalled carbon nanotubes (SWCNT) in cholesteric liquid crystals comprising a mixture of cholesterol esters and azoxy nematic ZhK-440. The optical density was shown to be essentially non-linear with SWCNT concentration, with a minimum ascribed to formation of "stacked" aggregates of nanotubes. The location of this minimum, as well as the selective reflection maximum (helical pitch), are sensitive to partially reversible UV-induced trans-cis-trans isomerisation effects. The UV-controlled helical pitch variation was shown to be only slightly affected by introduction of carbon nanotubes. Application prospects of such materials in optoelectronic devices are considered.

Представлены результаты по оптическому пропусканию и селективному отражению для дисперсий одностеночных углеродных нанотрубок (ОУНТ) в холестерических жидких кристаллах, состоящих из смеси эфиров холестерина и азокси-нематика ЖКК-440. Показано, что оптическая плотность изменяется с концентрацией ОУНТ существенно нелинейно, с минимумом, предположительно объясняемым агрегацией нанотрубок по типу стекинга. Положение этого минимума, как и длины волны максимума селективного отражения (шага спирали), чувствительно к әфёфектам частично обратимой транс-цис-транс изомеризации, вызываемой УФ-облучением. Показано, что введение углеродных нанотрубок лишь незначительно влияет на управляемое изменение шага спирали. Обсуждаются возможности использования таких материалов в оптоэлектронных устройствах.

Дисперсії вуглецевих нанотрубок у холестеричних рідких кристалах з фотоактивними компонентами. О.М.Самойлов, С.С.Міненко, Л.М.Лисецький, М.І.Лебовка, М.С.Соскін, С.І.Торгова.

Наведено результати з оптичного пропускання та селективного відбивання для дисперсій одностінкових вуглецевих нанотрубок (ОВНТ) у холестеричних рідких кристалах, що містять суміш естерів холестерину та азокси-нематик ЗЖК-440. Показано, що оптична густина змінюється істотно нелінійно з концентрацією ОВНТ, з мінімумом, який трактується як наслідок утаорення агрегатів нанотрубок стекінгового типу. Положення мінімуму, як і довжина хвилі максисуму селективного відбивання (крок спіралі), чутливі до частково оборотних ефектів УФ-індукованої транс-цис-транс ізомеризації. Показано, що внесення вуглецевих нанотрубок спричиняє лише незначний вплив на УФ-індуковані зміни кроку спіралі. Розглядаються можливості застосування таких матеріалів в оптоелектронних пристроях. 


\section{Introduction}

Dispersions of carbon nanotubes (CNT) in liquid crystals (LC) are gradually becoming a promising base for a new class of nanomaterials with broad prospects of applications [1-3]. The main technological problem in development of such materials is that characteristics of LC+CNT dispersions are not stable in time because of tendency of CNTs to aggregation in the LC medium. Various ways have been proposed to deal with this problem, including addition of specially designed components and development of specific preparation methods [4-6] or just using CNTs of shorter lengths at low concentrations (see, e.g., [7]). The latter approach can be useful for some applications, such as LC electrooptics, but it is not applicable when the LC medium is used just for orientation of CNTs, e.g., for their deposition on substrates [8] or applications based on electrophysics, such as variation of dielectric properties [9]. The problem of time instability of LC+CNT system has been treated both experimentally and theoretically from the viewpoint of molecular physics [10-12], where a physical picture of CNT aggregation was proposed, with appropriate recommendations on the ways to optimize the composition of LC+CNT system allowing suppression of the aggregation processes. It has been shown [13-15] that addition of chiral components to nematic LC matrices, which transforms a nematic LC into an induced cholesteric LC with nematic-like orientational ordering and helical twisting of the nematic director, can substantially decelerate and/or largely suppress the processes of CNT aggregation. So, if we concentrate ourselves on the optical and electrooptical effects in induced cholesterics (including electric field-induced helix untwisting - a cholesteric liquid crystal (CLC) analog of the Freedericks transition [16, 17] or UV-induced variation of helical pitch, e.g., for CLC-based tunable dye lasers $[18,19]$ ), doping of LC matrices with CNTs can lead to certain positive effects (as in nematics) without accompanying problems related to time instability due to CLC aggregation.

Recently, a pioneering work in this direction has been published [20], where effects of dispersed CNTs upon photoinduced transformations in CLC systems were studied. In this paper, a nematic mixture MLC6608 was doped with photosensitive chiral component 2-(4'-phenylbenzylidene)$p$-menthane-3-one (PBM). Under UV irradia- tion, PBM molecules undergo irreversible trans-cis isomerization with the corresponding decrease in helical twisting and higher helical pitch (longer wavelength of maximum selective reflection $\lambda_{\max }$ ) of the induced cholesteric. This process was studied in detail in $[21,22]$ without nanotubes, and in [20] the addition of dispersed CNTs made the phototransformation process noticeably (by about 4 times) slower. The offered explanations involved both lower effective exposure dose due to UV light absorption by CNTs over the sample thickness and certain specific interaction between CNTs and CLC molecules. A possible contribution from the first factor was validated in [23] using a different LC+CNT system, though the general mechanism remained unclear.

In our work, we used an induced cholesteric matrix comprising azoxy nematic LC mixture ZhK-440 and a mixture of cholesterol esters. The photoinduced effects in this system were studied in $[18,19$, 24 ], and reversible variation of $\lambda_{\max }$ under UV irradiation due to trans-cis and cis-trans transformation of azoxy nematic molecules was observed. In this study, we used dispersions of multi- and single-walled CNTs in induced CLC matrices of the same composition, which were subjected to UV irradiation under the same conditions, with the aim of clearing up the effects of dispersed CNTs on photoinduced transformations in such systems.

\section{Materials and methods}

The basic induced CLC system was composed of $\sim 75 \%$ of photoactive nematic ZhK-440 (4-n-butyl-4'-methoxyazoxybenzene $+\quad 4$-n-butyl-4'-heptanoyl-azoxybenzene in $2: 1$ ratio) and $25 \%$ of mesogenic chiral dopant M5 (a mixture of cholesterol esters: $30 \%$ cholesteryl formate, $5 \%$ cholesteryl butyrate and $65 \%$ cholesteryl nonanoate). The cholesterol esters were obtained from Chemical Reagents Plant, Ukraine and used without further purification. The photoactive nematic material was obtained from NIOPIK, Russia, and additionally purified by column chromatography on silicagel using a mixture of petroleum ether and benzene as the eluent. After evaporation of the solvent, the material was recrystallised from hexane at $-20^{\circ} \mathrm{C}$. In parallel comparative experiments, we also used a standard nematic 5CB (4-n-pentyl-4'-cyanobiphenyl) of $99.5 \%$ purity obtained from Chemical Reagents Plant, Ukraine. The single-walled 
carbon nanotubes (SWCNT) of $d \sim 1.5 \mathrm{~nm}$ and $l \sim 5-10 \mu \mathrm{m}$ were obtained from Arry, Germany. The LC+CNT dispersions within 0.01-0.15\% CNT concentration range were obtained by adding the appropriate weights of the nanotubes to the LC solvent in the isotropic state with subsequent $20-30 \mathrm{~min}$ sonication of the mixture using a UZD$22 / 44$ ultrasonic disperser (Ukrrospribor, Sumy, Ukraine), in accordance with procedure essentially similar to the previously described $[10,12]$.

UV irradiation was carried out using a DRT-240 Hg lamp emitter in geometry with known spectral distribution of illuminance [25]. A typical UV radiation dose was $1.9 \mathrm{~J} / \mathrm{cm}^{2}$, which, according to [26], resulted in a photostationary state with about $50 \%$ of azoxy molecules in cis form. The reverse cis-trans transition was realized by irradiation under the same condition using a ZhS-10 filter cutting off the wavelengths below $\sim 400 \mathrm{~nm}$, in the same way as in our previous works $[19,21]$. Optical transmission was measured using a Shimazu UV2450 (Japan) spectrophotometer within 300-900 $\mathrm{nm}$ spectral range. A sandwichtype LC cells (20 $\mu \mathrm{m}$ thickness) were used. The cell walls were treated with polyvinyl alcohol water solution and, after drying, rubbed in one direction to obtain the planar texture [25]. The sample was introduced between the cell walls using the capillary forces at the temperatures above the transition to the isotropic phase. The measurements were done within the temperature range of $20-60^{\circ} \mathrm{C}$ in the heating and cooling modes, and the temperature was stabilized using a flowing-water thermostat $( \pm 0.1 \mathrm{~K})$. The optical transmission data obtained in a wide wavelength range were used for two purposes. In the range of selective reflection (500-650 $\mathrm{nm})$, we determined the wavelength of maximum reflection $\lambda_{\max }$ $\left(\lambda_{\max }=n p\right.$, where $n$ is the average refractive index and $p$ is the pitch of the cholesteric helix. Also, we determined the values of optical transmission at $800 \mathrm{~nm}$, considered to be sufficiently far from any bands of selective reflection or absorption of the liquid crystalline host. The optical transmission data were recalculated to optical density values in the same way as in our previous paper [23].

\section{Results and discussion}

The measurements carried out in our studies were rather numerous, with optical
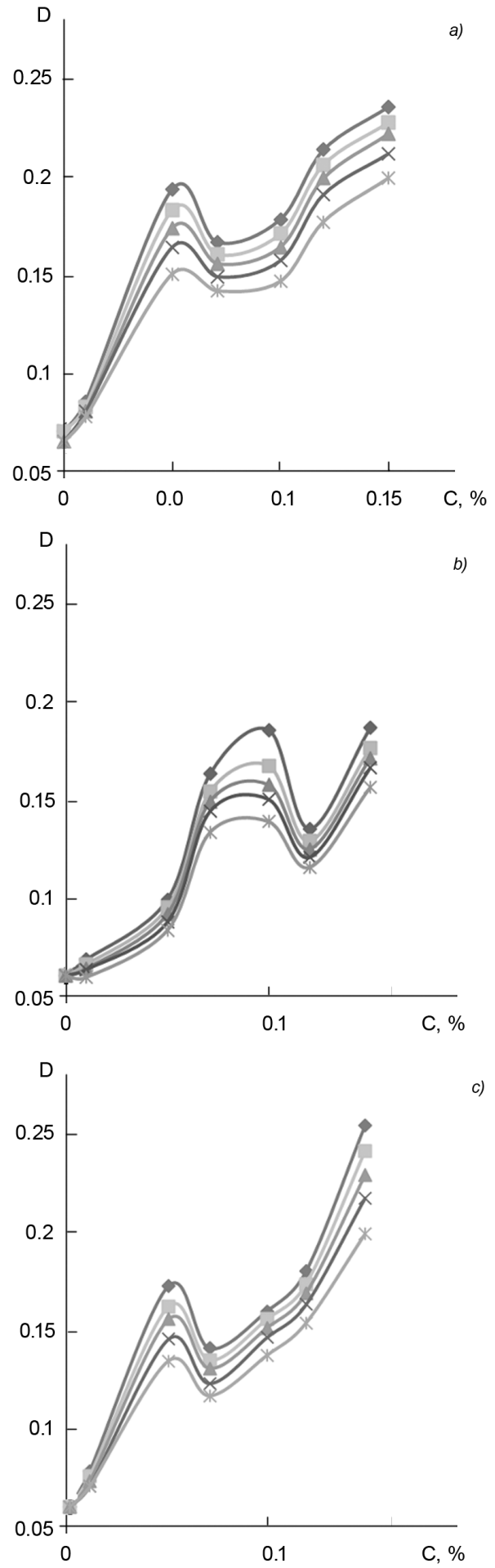

Fig. 1. Optical densities at $800 \mathrm{~nm}$ of cholesteric liquid crystal system $25 \%$ M5 + $75 \%$ ZhK-440 with dispersed single-walled carbon nanotubes at different temperatures as function of nanotube concentration: before irradiation (a), after 15 min UV irradiation (b) and after subsequent 30 min irradiation with ZhS-10 filter (c). From top to bottom: $20^{\circ} \mathrm{C}, 30^{\circ} \mathrm{C}, 40^{\circ} \mathrm{C}, 50^{\circ} \mathrm{C}, 60^{\circ} \mathrm{C}$. 


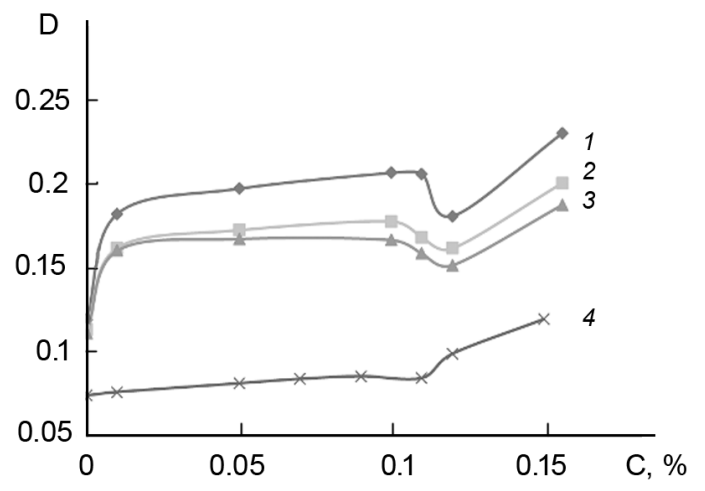

Fig. 2. Optical densities at $800 \mathrm{~nm}$ of cholesteric liquid crystal systems $25 \% \mathrm{M} 5+$ $75 \%$ 5CB (1-3) and M5 (4) vs. concentration of dispersed SWCNTs: $1-30^{\circ} \mathrm{C}, 2-38^{\circ} \mathrm{C}$, $3-40^{\circ} \mathrm{C}, 4-72^{\circ} \mathrm{C}$.

transmission and selective reflection (for CLC systems) measured for LC+CNT dispersions at different temperatures, different CNT concentrations and varied composition of the LC matrix. Here we present the most representative typical data obtained with SWCNT; the results with MWCNT were basically similar, and only some peculiar differences were noted.

Figure 1 shows optical density vs. SWCNT concentration in the $25 \% \mathrm{M} 5+$ $75 \%$ ZhK-440 CLC matrix: before (a) and after (b) UV irradiation, as well after subsequent irradiation with ZhS-10 filter (c). The obtained dependences were essentially non-linear, as distinct from the $5 \mathrm{CB}+\mathrm{SWCNT}$ system with a rather good conformity to the Bouguer-Lambert-Beer law [23]. Moreover, after UV irradiation the $D(c)$ plots were subject to substantial changes, with the initial picture being largely recovered after the "reverse" irradiation, suggesting substantial effects of trans-cis isomerization of the azoxy molecules of ZhK-440. (To make the effect more obvious, one could consider only the CNT concentrations not exceeding $0.01 \%$ - in this case, the effect would be even more striking - the optical density minimum would completely disappear after irradiation!). Taking into account the higher CNT concentrations, we can note that the $D$ minimum shifted from $\sim 0.08 \%$ to $\sim 0.12 \%$, returning to its initial location after the second irradiation. This effect was reproduced in dozens of experiments carried out at different temperatures with different freshly prepared dispersions.

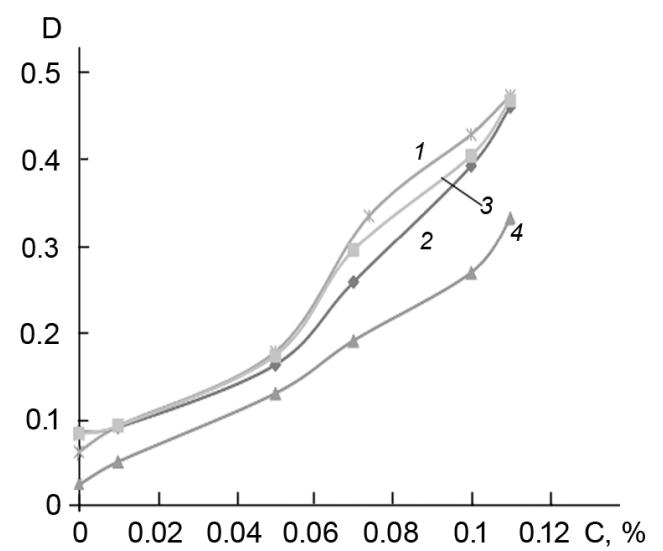

Fig. 3. Optical densities at $800 \mathrm{~nm}$ of nematic ZhK-440 (1-3) and nematic 5CB (4) vs. concentration of dispersed SWCNTs at $25^{\circ} \mathrm{C}$ : before irradiation $(1,4)$, after $15 \mathrm{~min} \mathrm{UV}$ irradiation (2) and after subsequent $30 \mathrm{~min}$ ir radiation with ZhS-10 filter (3).

Our initial assumption ascribed this effect to peculiar interaction features of ZhK440 azoxy molecules with CNTs (effects of LC negative dielectric anisotropy upon LC+CNT were noted in [27]). However, substituting 5CB for $\mathrm{ZhK}-440$ resulted in a qualitatively similar (though less marked) behavior (Fig. 2); even SWCNT dispersions in M5 (a cholesterol esters mixture without aromatic nematic components) showed a similar minimum on the $D(c)$ plot (Fig. 2, curve 4). In another control experiment, we studied ZhK-440+ SWCNT dispersions without a cholesteric component (Fig. 3). Both before and after irradiation the $D(c)$ dependence was monotonous, being essentially similar to that obtained for $5 \mathrm{CB}+\mathrm{SWCNT}$ in [23] (Fig. 3, curve 4). Thus, the only reasonable source of the observed unusual effect could be the cholesteric helical twisting of the system.

A possible physical mechanism could be naturally related with the CNT aggregate formation. Really, the CNT concentration of the aggregate formation threshold was earlier estimated as $\sim 0.05-0.1 \%$ for CNTs of similar dimensions $[11,12,28]$, and the onset of the $D(c)$ minimum should be naturally related to the appearance of emerging CNT aggregates. However, in another set of studies $[14,15]$ we have definitely stated that the presence of cholesteric components and helical twisting suppress the formation of CNT aggregates. The only possibility was to assume that the aggregates formed in our case were not the fractal S-aggregates 


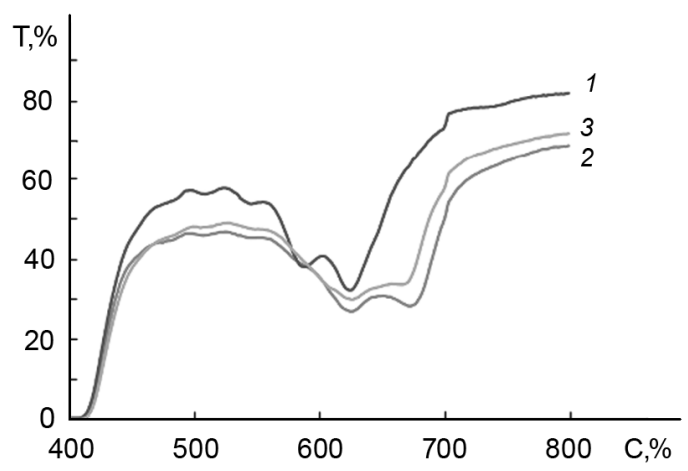

Fig. 4. Selective reflection peaks (at $20^{\circ} \mathrm{C}$ ) of the system $25 \%$ M5 + ZhK-440 + $0.05 \%$ SWCNT: 1 - before irradiation, 2 - after 15 min UV irradiation, 3 - after subsequent 30 min irradiation with ZhS-10 filter.

[10-12], but some CNT structures of a different nature.

A tentative explanation could be as follows. The conventional fractal S-aggregates, though oblate (flattened) in their general shape on a larger scale, in the nematic phase still retained "nematic" cylindrical symmetry of the nearest vicinity of each nanotube. The local phase biaxiality as an essential condition for the helical twisting [29] breaks this local cylindrical symmetry - the nanotubes, located and oriented within quasi-nematic layers [30], can bend only in the plane normal to the helical axis [28]. Thus, the effective shape of a CNT becomes flattened, and a new possibility emerges - something like "stacking" of adjacent nanotubes located in the neighboring quasi-nematic planes. In the nematic phase (no helix), individual CNTs are, though orientationally ordered, distributed randomly over the cell volume; when the local phase biaxiality appears with the helical twisting, some of the CNTs become "stacked" directly below the "upper" CNT on the way of the light beam; thus they become "screened" and do not contribute to the absorption and scattering processes on the molecular ("nanoparticle") level. This is observed as an apparent decrease in optical density. When the CNT concentration is increased further, the "natural" mechanism of Bouguer-Lambert-Beer type becomes predominant, and $D$ increases linearly with increased overall concentration of CNTs and their "stacked" aggregates. One should note that the effective extinction coefficient. A corresponding model quantitative description will be presented in our forthcoming publications; it will also account for the effects caused by UV radiation (basically ex-

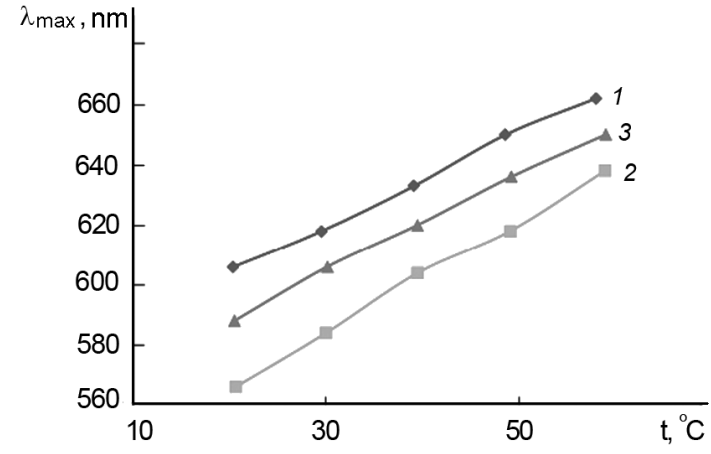

Fig. 5. Wavelengths of maximum selective reflection $\lambda_{\max }$ as function of temperature for the system $25 \%$ M5 + ZhK-440+ $0.05 \%$ SWCNT: 1 - before irradiation, $2-$ after 15 min UV irradiation, 3 - after subsequent 30 min irradiation with ZhS-10 fil-

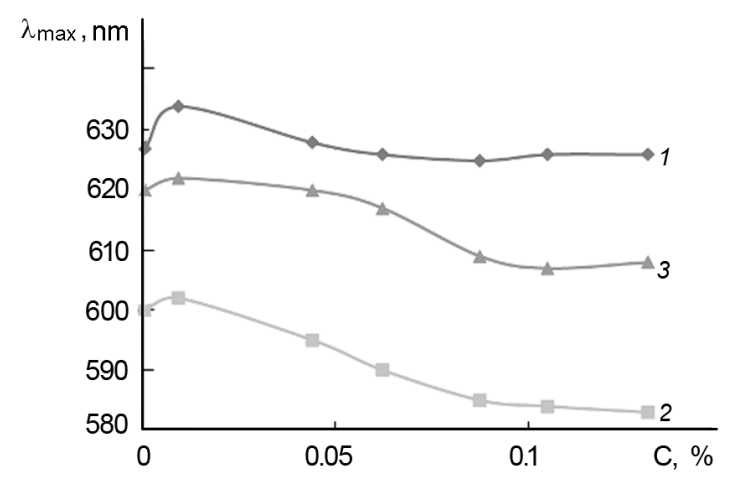

Fig. 6. Wavelength of maximum selective reflection $\lambda_{\max }\left(\right.$ at $\left.40^{\circ} \mathrm{C}\right)$ as function of nanotube concentration for the system $25 \% \mathrm{M} 5+$ $75 \%$ ZhK-440 + $0.05 \%$ SWCNT: 1 - before irradiation, 2 - after 15 min UV irradiation, 3 - after subsequent 30 min irradiation with ZhS-10 filter.

plained by changes in the short-range liquid crystal ordering due to appearance of cisisomers having different molecular shape).

\section{Conclusions}

Finally, we present our results on the effects of UV radiation upon helical twisting. Typical view of the selective reflection spectra (measured in the same conditions and in the same cells) is shown in Fig. 4. The peaks of the studied multicomponent cholesteric systems were somewhat smeared, which became even stronger upon addition of CNTs. However, using a large set of experimental data, reasonable $\lambda_{\text {max }}$ values could be determined (basing on the midpeak wavelength); representative examples of $\lambda_{\max }$ dependences on temperature and 
CNT concentration are shown in Figs. 5, 6 . From these data, two main conclusions can be made. First, introduction of CNTs at concentrations up to $0.15 \%$ did not significantly affect the irradiation-induced partially reversible shifts of $\lambda_{\max }$ - the general picture was rather similar to that observed without nanotubes $[19,24]$. Thus, such systems can combine the optical properties of phototunable cholesterics and electrophysical properties (e.g., high anisotropic conductivity) of $\mathrm{LC}+\mathrm{CNT}$ dispersions, suggesting possible applications in optoelectronic devices. Another interesting result is that the magnitude of the overall shortwave shift of $\lambda_{\max }$ under UV irradiation for $15 \min \left(\sim 2 \mathrm{~J} / \mathrm{cm}^{2}\right)$ did not significantly change with increased CNT concentration. This is in apparent contradiction with data of [20], where introduction of nanotubes made the trans-cis transformation significantly slower. A possible explanation is that we measured only the total shift at a specified exposure dose, which should correspond to saturation of the isomerization reaction. Further experiments are under way to study kinetics of the process at its initial stage.

\section{References}

1. M.Rahman, W.Lee, J.Phys.D:Appl.Phys., 42, 063001 (2009).

2. J.P.F.Lagerwall, G.Scalia, Curr.Appl.Phys., 12, 1387 (2012).

3. L.N.Lisetski, S.S.Minenko, A.P.Fedoryako, in: Functional Materials for Scintillation Techniques and Biomedicine, ISMA, Kharkov (2012), p.245 [in Russian].

4. S.Schymura, G.Scalia, Phil.Trans.Roy.Soc.A, 371, 2012021 (2013).

5. M.Kuhnast, C.Tschierske, J.Lagerwall, Chem. Commun., 46, 6989 (2010).

6. Y.Ji, Y.Y.Huang, E.M.Terentjev, Langmuir, 27, 13254 (2011).

7. Y.J.Lim, S.S.Bhattacharya, W.Tie et al., Liq. Cryst., 40, 2002 (2013).

8. M.D.Lynch, D.L.Patrick, Nano Lett., 2, 1197 (2002).
9. O.Trushkevych, F.Golden, M.Pivnenko et al., Electron Lett., 46, 693 (2010).

10. S.S.Minenko, L.N.Lisetski, A.I.Goncharuk et al., Functional Materials, 17, 454 (2010).

11. L.N.Lisetski, N.I.Lebovka, S.V.Naydenov, M.S.Soskin. J. Mol. Liq., 164, 143 (2011).

12. L.N.Lisetski, S.S.Minenko, V.V.Ponevchinsky et al., Mat.Sci.Eng. Technol., 42, 5 (2011).

13. A.M.Chepikov, S.S.Minenko, L.N.Lisetski et al., Functional Materials, 19, 343 (2012).

14. L.N.Lisetski, S.S.Minenko, A.P.Fedoryako et al., Functional Materials, 20, 153 (2013).

15. N.I.Lebovka, L.N.Lisetski, M.I.Nesterenko et al., Liquid Crystals, 40, 968 (2013).

16. P.Oswald, in: Phase Transitions, Application to Liquid Crystals, Electric and Electrooptic Fields, ed. V.Popa-Nita, Research Signpost, Trivandrum (2006), Chapt.3, p.47.

17. L.M.Blinov, Structure and Properties of Liquid Crystals, Springer, Dordrecht e.a. (2011).

18. I.Il'chishin, L.Lysetskiy, T.Mykytyuk et al., Mol. Cryst. Liq. Cryst., 542, 221 (2011).

19. I.P.Ilchishin, L.N.Lisetski, T.V.Mykytiuk, Opt.Mat.Express, 1, 1484 (2011).

20. O.Yaroshchuk, S.Tomilko, I.Gvozdovskyy, R.Yamaguchi, Appl.Opt., 52, E53 (2013).

21. I.Gvozdovskyy, O.Yaroshchuk, M.Serbina, Mol. Cryst. Liq. Cryst., 546, 202 (2011).

22. I.Gvozdovskyy, O.Yaroshchuk, M.Serbina, R.Yamaguchi, Opt. Express, 20, 3499 (2012).

23. A.N.Samoilov, S.S.Minenko, A.P.Fedoryako et al., Functional Materials, 21, No.2 (2014) [in press].

24. I.P.Ilchishin, L.M.Lysetskiy, T.V.Mykytiuk, M.I.Serbina, Ukr.Zh.Fiz., 56, 333 (2011).

25. L.N.Lisetski, V.D.Panikarskaya, N.A.Kasian et al., Proc. SPIE, 6023, 6023OF (2005).

26. D.Aronzon, E.P.Levy, P.J.Collings et al., Liq. Cryst., 34, 707 (2007).

27. P.Kalakonda, R.Basu, R.Nemitz et al., J. Chem. Phys., 140, 104908 (2014).

28. L.N.Lisetski, A.M.Chepikov, S.S.Minenko et al., Functional Materials, 18, 143 (2011).

29. G.S.Chilaya, L.N.Lisetski, Mol.Cryst.Liq. Cryst., 140, 243 (1986).

30. L.N.Lisetski, S.S.Minenko, A.V.Zhukov et al., Mol. Cryst. Liq. Cryst., 510, 43 (2009). 